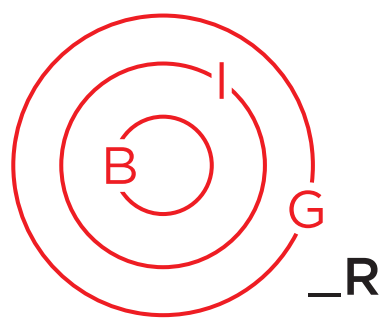

ESSAY

SPECIAL ISSUE

\title{
Brazilian Border Closures in Pandemic Times: A Comparative Approach to Four Regions
}

\author{
Licio Caetano do Rego Monteiro \\ Luís Paulo Batista da Silva ii \\ Rebeca Steiman iii \\ Leticia Parente Ribeiro iv
}

This paper discusses the context and the effects of border closures related to the COVID-19 pandemic in four border regions between Brazil and its neighbors, namely Venezuela, Colombia, Paraguay, and Argentina, from March to July 2020. The study highlights the low level of coordination among countries, bilateral or regional, in the course of the sanitary emergency. It also analyses the local impacts of the restrictive measures, especially on the twin cities due to their high level of interdependence, in which the inhabitants suffered from the dismantling of supply networks, the precarity of health services, and the economic downturn related to border closures.

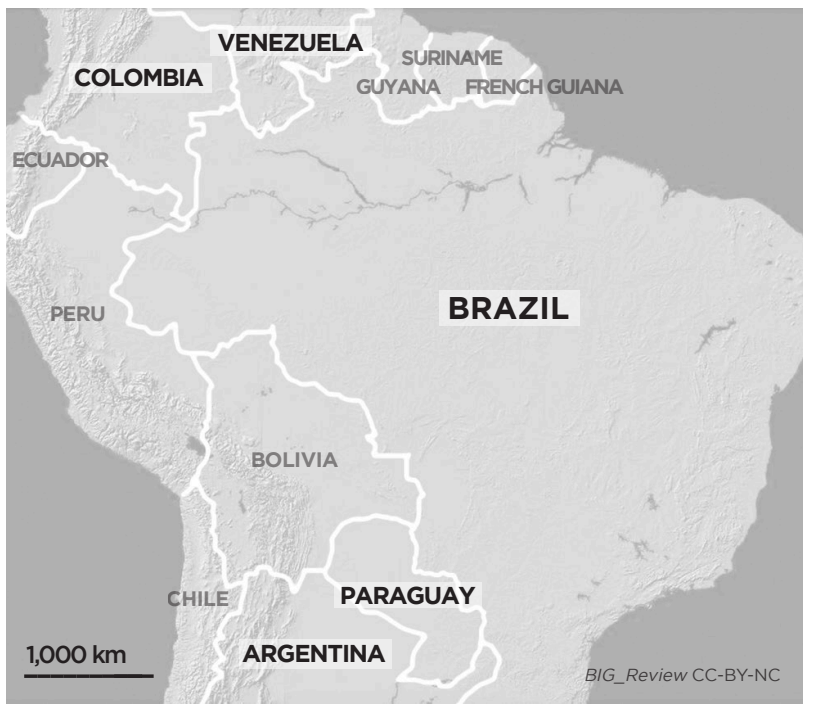

\section{Introduction}

Border closure has been a standard strategy throughout the world since the outbreak of the COVID-19 pandemic. The circulation of people was restricted or forbidden not only across terrestrial boundaries, but also at passenger terminals at seaports and airports. Within countries, different types of barriers were put in place by state authorities between provinces, cities, public and private spaces, and by communities that sought self-isolation.

The first cases of the novel coronavirus were reported in Ecuador and Brazil in late February. Argentina, Chile, Peru, Colombia, Paraguay and French Guiana announced their first cases in the beginning of March. When the World Health Organization (WHO) declared COVID-19 a global pandemic on March 11th, 2020, community transmission had already been detected in the subcontinent.

\footnotetext{
i Licio Caetano do Rego Monteiro, PhD, Universidade Federal Fluminense, Brazil. Contact: liciocaetano@id.uff.br

ii Luís Paulo Batista da Silva, PhD, Universidade Federal da Bahia, Brazil. Contact. luispbs@ufba.br

iii Rebeca Steiman, PhD, Universidade Federal do Rio de Janeiro, Brazil. Contact: rsteiman@igeo.ufrj.br

iv Leticia Parente Ribeiro, MSc, Universidade Federal do Rio de Janeiro, Brazil. Contact: leticiapr@igeo.ufrj.br
} 
On March 16th, official representatives of most countries in the region gathered in a videoconference. The need for restrictive measures, such as the closing of borders, was emphasized. Colombia complied first by closing its borders, followed by Peru, Paraguay, Argentina, and Bolivia. Brazil's absence at the meeting indicated its lack of interest in participating in coordinated regional actions to contain the pandemic.

In this paper, we point out the situation of four border regions between Brazil and its neighbors during the COVID-19 pandemic. More specifically, we analyze the implications of the legal measures implemented by national governments to contain the virus on border areas and their territorial effects, notably on spatial interactions at the twin cities. In this research, access to information was restricted to secondary sources, mainly news and reports, since we are all located outside the border zone. The conceptual framework and the analysis of the regional context result from the experience of more than two decades of research projects and fieldwork carried out in the Brazilian continental border. ${ }^{1}$

\section{Closing the Brazil-Venezuela Border: Political Hostilities and Health Issues}

The Brazil-Venezuela border closure occurred in the midst of ongoing hostilities between the two countries in view of the fact that the Brazilian government does not recognize the legitimacy of Nicolás Maduro's presidency. Between February and May 2019, Venezuela closed its borders in response to internal conflicts and alleged interference from the Brazilian government. ${ }^{2}$ Despite the difficulties throughout 2019, 129,000 asylum seekers crossed the border from Venezuela into Brazil (Mello 2020). Even when the border was reopened (from May 2019 to March 2020), there were episodes of blockage either by the Brazilian military control operations, in December 2019, or by protests of Brazilian citizens, in February 2020. Under these circumstances, the first cases of COVID-19 in Venezuela and in the state of Roraima, Brazil, were reported in March 2020.

This hostile situation explains why Brazil decreed the closure of the border with Venezuela by a specific ordinance, two days before closing its border with other neighbors. Ordinance 120, issued on March 17th, restricted the Venezuelan border down to Brazilian citizens and foreign residents returning from Venezuela, and to the transit of goods. The intense flow of immigrants and refugees in the past two years strained bilateral relations. It may also have amplified the expectation of an increased influx of Venezuelans in search of medical assistance into Brazil. However, unexpectedly, 1,696 Venezuelans returned to their country of origin in the month following the decree (Mello 2020).

Venezuela had more than 1,000 COVID-19 cases in June, as the contagion accelerated. As of July 2Oth, the country officially reported over 12,000 cases, 750 of which were in the state of Bolivar, including Santa Elena de Uairén, the twin city of Pacaraima in the Brazilian state of Roraima, the main crossing point between the two countries. The Venezuelan government also decreed partial opening in several states with lower rates of contagion, but maintained its lockdown in Bolívar. On the Brazilian side, until July 19th, the state of Roraima had 25,467 cases and 431 deaths, of which 1,002 cases and 18 deaths were in Pacaraima (Roraima 2020). Due to the fact that Brazil had not yet contained the pandemic in July (Brazil had rates circa 50,000 cases and 1,000 deaths daily then), Venezuela renewed the border closure ordinance.

Concerned about the return of its citizens from Brazil and Colombia along with the entry of citizens from higher-risk countries, the Venezuelan government adopted strict measures, including the imposition of curfews on border municipalities on May 19th and the arrest of Venezuelans who returned to the country illegally without observing quarantine periods in July (Infobae 2020).

\section{Brazil-Colombia: Up the River and into the Forest}

Brazil's first confirmed case of COVID-19 occurred two weeks before cases in Colombia and Peru. In the triple border region, the contagion dynamic seems closely related to the diffusion pattern of COVID-19 in Brazil and Peru, from the capital cities towards the interior. According to a transborder network lead by FIOCRUZ 3 that monitored the spread of the virus, three months after the first confirmed case in Manaus, capital of the state of Amazonas, Brazil, the novel coronavirus had reached almost all border municipalities in Brazil (60 of 62) and Peru (45 of 51) and 41 percent of them in Colombia (12 of 29) (Carvajal-Cortés et al 2020).

Control measures implemented by mid-March that included restrictions at land border crossings were unable to stop the circulation of people along the river and across the border, especially between the twin cities of Tabatinga, Brazil, and Leticia, Colombia. Those cities are the only significant gateway in this border region, mostly characterized by dense Amazon rainforest, small towns, and a prominent presence of indigenous populations. Distant from the major cities and accessible only by air or river, both Tabatinga and Leticia depend on their mutual supply of goods and services, which they also provide to surrounding localities. Under curfews and quarantine requirements, families, workers, and businesses suffered in these cities from cross-border restrictions and economic downturn (Luján 2020).

Throughout the 1990s and 2000s, the intensification of the Colombian conflict was accompanied by an increase in the performance and presence of Brazilian Armed Forces in the border region, which nevertheless remained quite active even after the peace agreements between 
the Colombian government and the main guerrilla groups in the country (Rego Monteiro 2016). With the outbreak, the enhanced military presence at the border's main crossing, Avenida da Amizade, created an environment conducive to the virus' spread, as it diverted entry routes to places lacking sanitary controls (Zárate Botía 2020, 5).

Dwellers suffer with the health system's cumulative precarity, lacking intensive care facilities and personnel and relying on aerial transfer of the more serious cases to Bogotá and Manaus. As for the indigenous population, inhabiting both urban and rural areas, the first fatality was reported on March 31st. As the authorities underestimated the threat and were reluctant to countenance it fully, the virus then spread among 47 different indigenous peoples inhabiting the tri-border region (Confederação das Organizações Indígenas da Amazônia Brasileira 2020). The Brazilian government's negligence has increased their risk of physical and cultural extinction. The risk is even higher among isolated and non-contacted groups, due to their demographic fragility and the ongoing illegal extractive activities that threaten their territories (Organización Nacional Indígena de Colombia 2020).

\section{Brazil-Paraguay: Closing Shops to Control the Virus}

The Brazil-Paraguay border region is characterized by intense cross-border interactions, mostly between the twin cities of Foz do Iguaçu, Brazil, and Ciudad del Este, Paraguay, South America's prominent trade hub. The Paraguayan Ministry of Health ordered the suspension of large open events, gatherings in closed places, and educational activities in the beginning of March.

As of July 29th Paraguay had 682 cases per million inhabitants, while Brazil and Argentina had respectively 12,016 and 3,958 cases per million (Our World in Data, 2020). Strict border control measures implemented by the Paraguayan government, that included the use of military personnel to prevent the entry of non-residents into Paraguay, fueled up tensions in the twin cities of Foz do Iguaçu and Ciudad del Este, leading Paraguay's president, Mario Abdo Benitez, to state in the beginning of May that "we would not dream of opening the border [to Brazil]".

The re-export trade in Paraguayan border cities is an activity responsible for around 25 percent of national exports and one of the country's largest employment sectors. Since the border closure, Ciudad del Este's re-export trade has seen a 95 percent drop in sales. Even after the quarantine loosening in June and the possibility of reopening commercial establishments, many shopping centers chose not to restart their activities, since Brazilian customers could not cross Ponte da Amizade (Agencia EFE 2020). The same trend has been observed in other twin cities, such as Pedro Juan Caballero, Salto del Guairá and Encarnación, along Paraguay's border where trade is of great economic importance.
A range of measures adopted to mitigate the effects of the pandemic in Brazil and Paraguay strained crossborder relations at the twin cities connected by land boundary crossings. In localities such as Pedro Juan Caballero, Paraguay, and Ponta Porã, Brazil, and Ypejhú, Paraguay, and Paranhos, Brazil, Paraguayan authorities have sought to make land crossings from Brazil more difficult by installing barbed wire on the public road that separates the two countries and excavating a trench with a backhoe (Carmo 2020). The mayor of Ypejhú justified the actions in late March saying that "we are very worried and there are many cases of coronavirus in Brazil. If there is a case here, we won't be able to handle it since we don't have a doctor, nothing. We can just protect ourselves" (Ultima Hora 2020).

\section{Brazil-Argentina: Curtailing MERCOSUR's Main Trade Route}

Across the border between Argentina and Brazil, the largest economies in the MERCOSUR economic bloc, the most volume of goods and merchandise between Latin American partners are traded. The closure of this border crossing has had important effects on economic and migratory flux, and on border locations.

The twin cities of Paso de los Libres, Argentina, and Uruguaiana, Brazil, are the main gateway for binational trade. The frequent contact between Argentinian residents and foreign transporters concerned both local and national authorities, since many cargo trucks depart from São Paulo, Brazil, one of the most severely infected places on the continent. Until the beginning of July, there was only one registered case in a resident of Paso de los Libres; however, other cases have been reported in transit people. This has led the city council to install a sanitary checkpoint in the city's junction with the highway that connects it to Buenos Aires (Pereira 2020). Despite the attempt to maintain the flow of binational trade since April, cargo traffic through the Uruguaiana customs post has decreased by approximately half (Marcovici 2020).

Finally, the border closure and the disruption of tourist activities have also impacted the triple border between Brazil, Argentina, and Paraguay, where the Iguazu Falls, an important tourist destination, is located. At the peak of the 2019 tourist season, the Argentinian city of Puerto Iguazu received about 200,000 visitors monthly, which was of great importance to its local economy. Even with the recent partial reopening of trade, local authorities point out that this will not be enough to revive the economy, as the number of tourists is still quite low.

\section{Final Remarks}

This brief review of the situation of different regions of the Brazilian continental border during the COVID-19 pandemic has shown an increase in tensions with 
neighboring countries, due to Brazil's alleged inability to contain the spread of contagion in its territory.

Despite the rather weak regional coordination of actions, there has been a widespread use of "closing borders" to the traffic of foreigners and non-residents while safeguarding free cargo circulation. On the other hand, the intensity of the control measures and the penalties stipulated in cases of non-compliance have varied significantly from country to country. The dominant trend was for neighboring countries to adopt a more rigid position than Brazil in relation to cross-border transit. However, none of the countries analyzed in this report has adopted measures for mass testing or tracing contacts throughout the pandemic, even in places of cross-border transit which, meanwhile, have remained interrupted.

Regarding the territorial effects of the measures implemented to contain the advancement of the new coronavirus, there has been significant disruption in the local cross-border economic circuits, especially in the twin cities, as well as in the access of the inhabitants of the border region to health services and infrastructure.

This analysis points toward the necessity to further investigate the consequences of the militarization of sanitary actions in border regions, in a context in which the health problem is treated as a security issue.

\section{Notes}

1 We would like to thank the two anonymous reviewers for their valuable suggestions and comments.

2 In February 2019, the Brazilian government sent trucks with "humanitarian aid" to Venezuela at the same time that self-proclaimed Venezuelan President Guaidó was trying to bring in "humanitarian aid" into the country from Colombia. President Maduro considered the Brazilian action political interference orchestrated with Venezuelan dissidents and ordered the closure of the border between the two countries.

3 See https://amazonia.fiocruz.br/?page_id=31692.

\section{Works Cited}

Agencia EFE. 2020. "Ciudad del Este está en 'duelo empresarial' por cierre de la frontera con Brasil". Agencia EFE (May 18). Available: https://www.efe.com/efe/america/economia/ ciudad-del-este-esta-en-duelo-empresarial-por-cierre-dela-frontera-con-brasil/20000011-4249452

Brasil.2020."PortariaN.120, de17demarçode2020". Government of Brazil (March 17). Available: https://www.in.gov.br/web/ dou/-/portaria-n-120-de-17-de-marco-de-2020-248564454

Carmo, Marcia. 2020. “'É a principal ameaça’: situação de pandemia no Brasil gera temor em vizinhos na América do Sul." BBC News-Brasil (May 12). Available: https://www.bbc. com/portuguese/internacional-52594649
Carvajal-Cortés, José Joaquim; Suárez- Mútis, Martha; Rapozo, P. H. C.; Reis, R. O. B. 2020. "Cenários epidemiológicos da pandemia da COVID-19 na tríplice fronteira - Boletím 1" Rede transfronteiriça para o enfrentamento da pandemia por COVID-19. Available: https://amazonia.fiocruz.br/wp-content/uploads/2020/07/boletin1red_pt_ES1.pdf

Confederação das Organizações Indígenas da Amazônia Brasileira. 2020. "COVID-19 e povos indígenas da Amazônia". Informativo COIAB (July 18). Available: https://coiab.org.br/ conteudo/1588782285410×773867293111222300

Infobae. 2020. "El régimen de Nicolás Maduro amenaza a los migrantes que retornan a Venezuela por pasos ilegales: 'Les hemos declarado la guerra"'. Infobae (July 17). Available: https://www.infobae.com/america/venezuela/2020/07/17/el-regimen-de-nicolas-maduro-amenaza-a-los-migrantes-que-retornana-venezuela-por-pasos-ilegales-les-hemos-declarado-la-guerra/

Luján, Patrícia M. 2020. “El COVID-19 'infecta' con incertidumbre e inestabilidad el comercio en las ciudades de frontera de Leticia y Tabatinga". Notimani, vol. 44-45 (May-June): 16-17. Available: https:// issuu.com/dcchicov/docs/notimani_44___45_mayo_-junio_20201

Marcovici, Fred. 2020, "Comércio entre Brasil e Argentina despenca em abril de 2020 devido a pandemia". Correio do Povo (May 13). Available: https://www.correiodopovo.com.br/not\%C3\%ADcias/cidades/com\%C3\%A9rcio-entre-brasil-e-argentinadespenca-em-abril-de-2O2O-devido-a-pandemia-1.421747

Mello, Michele. 2020. "Mais de 28,5 mil venezuelanos regressaram ao país durante a pandemia". Brasil de Fato (May 07). Available: https://www.brasildefato.com.br/2020/05/07/ mais-de-28-5-mil-venezuelanos-regressaram-ao-pais-durante-a-pandemia

Organización Nacional Indígena de Colombia. 2020. "Boletín 036. Sistema de Monitoreo Terrestre" (June 23). Available: https://www.onic.org.co/noticias/3940-boletin-036-sistema-de-monitoreo-territorial-smt-onic-informacion-para-proteger-la-vida-y-los-territorios

Our World in Data. "Coronavirus (COVID-19) Cases". Our World In Data (July 28). Available: https://ourworldindata.org/covid-cases

Pereira, Alfredo. 2020. "Medidas de prevenção ao coronavírus são adotadas em Uruguaiana, na fronteira com a Argentina." G1 (March 14). Available: https://g1.globo.com/rs/ rio-grande-do-sul/noticia/2020/03/14/medidas-de-prevencao-ao-coronavirus-sao-adotadas-em-uruguaiana-na-fronteira-com-a-argentina.ghtml

Rego Monteiro, Licio C. 2016. "Brazilian security policy in the Amazon border and securitization of the Colombian conflict (2001-2011)". Hemisferio, Revista del Colegio Interamericano de Defensa, vol.2: 81-99. Available: http://publications.iadc.edu/hemisferio-article/ brazilian-security-policy-in-the-amazon-border-e-mais/

Roraima. 2020. "Boletim epidemiológico, Coronavirus 169/2020". SESAU, Governo de Roraima (July 19). Available: https://saude.rr.gov.br/index.php/inform acoesxcoronavirus/informacoes-coronavirus/ file/1430-boletim-epidemiologico-coronavirus-169-2020

Ultima Hora. 2020. "Ypejhú: cavan fosas para evitar paso fronterizo ante falta de personal" (May 18). Available: https:// www.ultimahora.com/ypejhu-cavan-fosas-evitar-paso-fronterizo-falta-personal-n2875984.html

Zárate Botía, Carlos. 2020. "Cierre de la frontera: el problemático manejo local de una epidemia global". Notimani, vol. 44-45 (May-June): 4-8. Available: https://issuu.com/dcchicov/docs/ notimani_44_-_45_mayo_-_junio_20201 